\title{
Multiparameter Analysis of Clastogenic Factors, Pro-oxidant Cytokines, and Inflammatory Markers in HIV-1-Infected Patients with Asymptomatic Disease, Opportunistic Infections, and Malignancies
}

\author{
Jürgen Fuchs, ${ }^{1}$ Nicole Oelke, ${ }^{1}$ Matthias Imhof, \\ Falk Ochsendorf,' Helmut Schöfer,' Gerhard Oromek, ${ }^{2}$ \\ Amina Alaoui-Youssefi, ${ }^{3}$ and Ingrid Emerit ${ }^{3}$ \\ Departments of ${ }^{1}$ Dermatology and ${ }^{2}$ Internal Medicine, Frankfurt \\ University Hospital, Frankfurt am Main, Germany \\ ${ }^{3}$ Institut Biomedical des Cordeliers, Université Pierre et Marie Curie, \\ Paris, France \\ Accepted March 6, 1998.
}

\begin{abstract}
HIV-1-infected patients are in chronic oxidative stress and clastogenic factors (CFs) are present in their plasma. CFs from patients with HIV are formed via superoxide anion radical and stimulate further superoxide production. The pathophysiologic significance and the exact composition of the circulating clastogenic material in patients with HIV is unknown. Cytokines, such as tumor necrosis factor-alpha (TNF- $\alpha$ ), are increased in the plasma of patients with HIV and TNF- $\alpha$ shows clastogenic activity in vitro. The aim of this clinical study was to compare levels of CF in HIV-1-positive patients with asymptomatic disease, opportunistic infections, and malignancies with those in HIV-1-negative control groups and to correlate $\mathrm{CF}$ activity with $\mathrm{CD}^{+}{ }^{+} \mathrm{T}$ cell numbers, the cytokines (TNF- $\alpha$, interleukin-2 [IL-2], IL-6), and the inflammatory markers (C-reactive protein [CRP], neopterin, granulocyte elastase). CFs were significantly increased in all HIV-1-positive patients and in HIV-1-negative patients with malignant tumors. HIV-1-positive patients with Kaposi's sarcoma showed the highest CF
\end{abstract}

activity in their plasma $(p<0.08)$. CFs appear very early in HIV infection, and they correlate negatively with $\mathrm{CD}^{+} \mathrm{T}$ cells, which are an indicator of disease activity. The presence of CF in the plasma of HIV-infected patients is not a general response to a viral infection because these factors are not increased in HIV-1-negative patients with viral infection (zoster). CFs are not specific for the HIV-1 infection; they also occur in HIV-1-negative patients with malignant tumors. There was a tendency towards a positive correlation $(p<0.14)$ between CF and TNF- $\alpha$, but there was no positive correlation of CF with IL-2, IL-6, CRP, elastase, and neopterin levels. This indicates that TNF- $\alpha$ may be among the components of CF in HIV-1-infected patients. In addition, other unidentified components may contribute to the clastogenic activity of the plasma or the composition of $\mathrm{CF}$ may vary from patient to patient. Further clinical studies with larger sample populations are necessary to analyze the composition of CF in HIV-1-positive patients.

\section{Introduction}

Clastogenic factors (CFs) are chromosome-damaging agents with low molecular weight

Address correspondence and reprint requests to: Dr. Jürgen Fuchs, Privatdozent, Heinsestrasse 8, 63739 Aschaffenburg, Germany. Phone: 43-6021-219825; Fax: 49-6021-219746.
$(<30,000$ daltons) that cause chromosome aberrations, sister chromatid exchanges, DNA strand breakage, and gene mutation. For more than 30 years they have been known to be an indirect effect of ionizing radiation $(1,2)$. Because of their persistence in the blood of irradiated persons many years after exposure (3), CF have been 
considered risk factors for late effects of ionizing irradiation such as cancer and leukemia (4). The presence of CF in plasma has also been described in patients with congenital breakage syndromes such as ataxia teleangiectasia, Fanconis anemia, and Bloom's syndrome, which are all associated with a high incidence of malignancies (5). The superoxide anion radical is implicated in clastogenic factor formation and action (6). This has been demonstrated particularly for CF derived from the plasma of patients with human immunodeficiency virus (HIV) (7). Recently, the presence of $C F$ was reported in patients infected with the HIV-1 virus (8).

Experimental evidence indicates that HIV-1infected patients are in oxidative imbalance, which starts early in the course of the disease. Cytokines, such as TNF- $\alpha(9,10)$ and IL-6 (11), and acute phase proteins, such as CRP (12) and neopterin (13), are increased in HIV-1-infected patients, while IL-2 (14) is decreased. These products may stimulate the cellular production of reactive oxygen species. Low levels of serum and tissue antioxidants and elevated concentrations of peroxidation products have been reported in HIV-infected patients (15-21). HIV induces immunosuppression that renders the body highly susceptible to opportunistic infections and malignancies. Oxidative stress may contribute to the immunosuppression, carcinogenesis, and stimulation of viral replication in HIV-infected patients (22-25).

The objective of this study was to compare levels of CF in the plasma of HIV-1-positive patients with asymptomatic disease, opportunistic infection (zoster), and malignancies ( $\mathrm{T}$ cell lymphomas, Kaposi's sarcoma) with those in HIV-1 negative control groups. We investigated the correlation of $\mathrm{CF}$ values with the $\mathrm{CD}^{+}{ }^{+} \mathrm{T}$ cells to learn about its indicator function for disease progression. In addition, the plasma levels of the cytokines IL-2, IL-6, and TNF- $\alpha$ and the acutephase proteins CRP, neopterin, and granulocyte elastase were correlated with CF activity to find out about the factors that may contribute to $\mathrm{CF}$ formation.

\section{Materials and Methods}

\section{Patients}

We examined 30 HIV-1-negative and 24 HIV-1positive out- and inpatients from the Departments of Dermatology and Internal Medicine, J. W. Goethe University Medical School, Frank- furt, Germany. The HIV-1-negative patients were subdivided into the following groups: HIVl-negative healthy controls $(n=10$, mean age 30 years; range $=23-69$ years; no antibiotic or antiviral drugs); HIV-1-negative patients with zoster infection $(n=10$, mean age 57 years, range $=36-82$ years; no antibiotic or antiviral drugs); and HIV-l-negative patients with malignant tumors ( $\mathrm{T}$ cell lymphomas, sarcomas), $(n=10$, mean age 56 years, range $=21-88$ years; no antibiotic or antiviral drugs). The HIV1-positive patients were stratified into the following groups: HIV-1-positive patients with asymptomatic disease $\left(\mathrm{CD}^{+}{ }^{+} \mathrm{T}\right.$ cell numbers $>$ $500 / \mathrm{ml})(n=10$, mean age 36 years, range $=$ 24-50 years); HIV-1-positive patients with zoster infection $(n=4$, mean age 53 years, range $=$ 43-67 years); and HIV-1-positive patients with malignant tumors (Kaposi's sarcoma $n=7$, T cell lymphomas $n=3),(n=10$, mean age 44 years, range $=33-63$ years). One HIV-l-positive patient with zoster also had Kaposi's sarcoma. Most of the HIV-1-positive patients received antibiotic or antiretroviral therapy. The HIV-1-negative patients with malignancies did not receive radiation therapy prior to collection of plasma. Patients and healthy subjects gave their informed consent to participate in this study, according to the Medical School's Ethics Committee regulations.

\section{Sample Preparation}

For evaluation of the clastogenic effects exerted by the patient's plasma, the blood was centrifuged. The plasma was ultrafiltered through an Amicon filter, which had a cutoff at 30,000 daltons (Amicon YM 30, Danvers, MA). This procedure removes all high-molecular-weight plasma components that might disturb culture growth because of blood group incompatibilities. In addition, it eliminates cells that might still be present in the plasma after centrifugation. The ultrafiltrates were then stored at $-80^{\circ} \mathrm{C}$ and delivered frozen to the Institut Biomedical des Cordeliers in Paris, where they were tested for their clastogenic activity in a cytogenetic test system. The preparation and analysis were carried out according to the standard procedure reported in detail elsewhere (26).

\section{Clastogenic Factor Test}

Aliquots of the ultrafiltrates $(0.25 \mathrm{ml})$ were added to the test cultures set up with $0.5 \mathrm{ml}$ 
whole blood from healthy blood donors, $5 \mathrm{ml}$ tissue culture medium (TCM 199 from Flow Laboratories, Paris) and $1 \mathrm{ml}$ fetal calf serum (FCS) (Gibco, Paris). In some cases, $0.25 \mathrm{ml}$ of the patients' ultrafiltrate caused significant cytotoxicity in the donor lymphocytes. Therefore, the assay was repeated with $0.1 \mathrm{ml}$ ultrafiltrate and the highest rates of chromosome aberrations were taken for the calculation of CF. In controls (healthy blood donors), $0.25 \mathrm{ml}$ or $0.1 \mathrm{ml}$ of plasma ultrafiltrates caused the same rate of chromosome aberrations. Lymphocyte proliferation was stimulated by addition of phytohemagglutinin (Wellcome Diagnostics, Dartford, U.K.). After $72 \mathrm{hr}$ of incubation at $37^{\circ} \mathrm{C}$, microscopic slides were prepared for chromosomal analysis according to standard procedures. Cultures of normal donor cells showed a small number of chromosomal aberrations, or so-called spontaneous aberrations. This background level of aberrations in the simultaneously untreated blood cultures was substracted from the aberration rate in the ultrafiltrate-treated cultures of the same blood donors. The difference between the two values is given as the level of CF (27). The plasma ultrafiltrates from about 100 healthy blood donors from the Centre de Transfusion in Paris showed a maximum of 6 CFs in $5 \%$ of the donors (historical control). A higher rate of $\mathrm{CF}$ was never observed, therefore $\mathrm{CF}>8$ is considered abnormal.

Inflammatory Markers, Cytokines, and $\mathrm{CD}^{+} \mathrm{T}$ Cell Analysis in Plasma

CRP (28) (Behring-Turbi-Time ${ }^{\circledR}$ test, Behring, Marburg, Germany), granulocyte elastase (29) (Immunoassay Ecoline ${ }^{\circledR}$ Merck, Darmstadt, Germany), neopterin (30) (Neopterin Immunoassay Merck, Darmstadt, Germany), TNF- $\alpha$ (Predicta ${ }^{\circledR}$, Genzyme Diagnostics Inc, Cambridge, MA), IL-2 (Interleukin-2 Immulite ${ }^{\circledR}$, DPC Biermann, Bad Nauheim, Germany) and IL-6 (Interleukin-6 Immulite ${ }^{\circledR}$, DPC Biermann, Bad Nauheim, Germany) were determined by commercially available test systems $(31-33)$. $\mathrm{CD}^{+} \mathrm{T}$ cells were analyzed in a Coulter counter for routine hematological analysis.

\section{Statistics}

The experimental data points showed a nonGaussian distribution, therefore nonparametric tests were selected for statistical analysis. The unpaired Kruskal-Wallis test was used for com- parison of multiple independent data points, and the Wilcoxon-Mann-Whitney test was applied for comparison of two independent data points. The Spearman rank test was applied as a nonparametric test for correlation analysis. A $p<$ 0.05 was considered significant.

\section{Results}

Clastogenic Factors

The plasma ultrafiltrates from HIV-1-positive patients with asymptomatic disease $(p<0.002)$, with zoster infection $(p<0.01)$, and with malignancies $(p<0.00008)$ induced a significant increase in chromosomal breakage in the cytogenetic test system compared with HIV-1-negative healthy controls. HIV-1-negative patients with malignant tumors also showed a significantly increased CF $(p<0.008)$. No increase in chromosome breaks was observed in test cultures exposed to plasma ultrafiltrates from HIV-1-negative patients with zoster infection compared with HIV-1-negative healthy controls (Table 1). HIV-1-positive patients with Kaposi's sarcoma tended to show the highest CF activity in plasma $(16 \pm 4.0)$, compared with all HIV-1-positive patients without Kaposi's sarcoma $(10 \pm 1.2 ; p<$ 0.08 ) (Table 1). There was no significant difference in CF in the plasma of smokers versus nonsmokers in healthy controls and patients. Furthermore, alcohol intake did not influence the CF in our patients and controls (data not shown).

\section{Cytokines}

The plasma levels of the cytokines TNF- $\alpha$, IL-2, and IL- 6 were generally within the normal range in all patients studied. However, TNF- $\alpha$ concentration tended to be elevated in HIV-l-negative patients with malignancies $(p<0.1)$ and in HIV1 -positive patients with malignancies $(p<0.09)$, in comparison with HIV-1-negative controls. HIV-1-positive patients with malignancies showed the highest TNF- $\alpha$ values (Table 1 ).

IL-6 was significantly increased in HIV-1negative patients with malignancies $(p<0.04)$ as well as in HIV-1-positive patients with asymptomatic disease $(p<0.04)$ and with zoster $(p<$ 0.04), compared with HIV-1-negative healthy controls. IL- 6 was significantly decreased in HIV1 -positive patients with malignancies in comparison to HIV-1-positive patients with asymptomatic disease $(p<0.0003)$ (Table 1$)$. IL-2 levels were inclined to be more increased in HIV-1- 


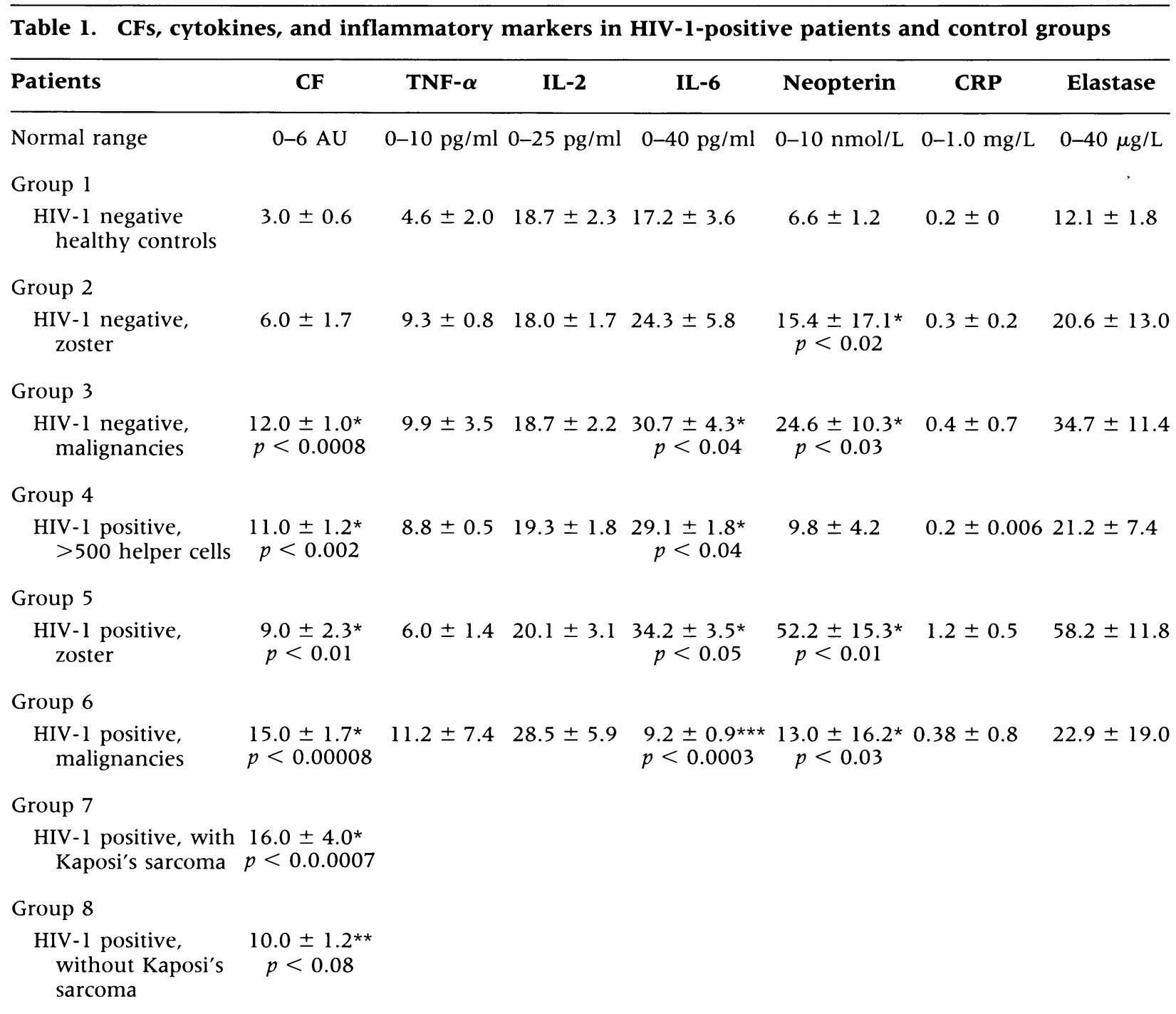

Values given are median \pm SD. *Statistically significant from group $1 ; * *$ almost statistically significant from group $7 ; * * *$ statistically significant from group 4 .

positive patients with malignancies $(p<0.1)$ (Table l) than in HIV-l-negative controls.

\section{Inflammatory Markers}

Neopterin levels were significantly increased in HIV-1-negative patients with zoster $(p<0.02)$ or malignancies $(p<0.03)$, and in HIV-1-positive patients with zoster $(p<0.01)$ or malignancies $(p<0.03)$. Neopterin was not elevated in HIV1-positive patients with asymptomatic disease (Table 1). Granulocyte elastase and CRP were inclined to be increased in HIV-positive patients with zoster $(p<0.1)$.

\section{Correlation Analysis}

CF tended to correlate negatively with $\mathrm{CD}^{+} \mathrm{T}$ cell numbers $(r=-0.37, p<0.1)$. This negative correlation reached statistical significance $(r=-0.44, p<0.05)$ when $0.1 \mathrm{ml}$ plasma ultrafiltrate was used for the cytogentic assay (see Materials and Methods). CF correlated negatively with IL-6 $(r=-0.43, p<0.05)$ and showed a tendency towards a positive correlation with TNF- $\alpha(r=0.31, p<0.14)$ (Table 2). $\mathrm{CD}^{+} \mathrm{T}$ cells correlated positively with IL-6 $(r=0.57, p<0.01)$, and $\mathrm{CD}^{+} \mathrm{T}$ cells showed a tendency towards a negative correlation with ne- 
Table 2. Spearman rank correlation analysis of $\mathrm{CF}, \mathrm{CD4}^{+} \mathrm{T}$ cells, cytokines, and inflammatory markers in HIV-1-infected patients

\begin{tabular}{|c|c|c|}
\hline Parameter & $r=$ & $p<$ \\
\hline CF/TNF- $\alpha$ & 0.31 & 0.14 \\
\hline CF/IL-6 & $(-) 0.43$ & 0.05 \\
\hline $\mathrm{CF} / \mathrm{CD} 4^{+} \mathrm{T}$ cells & $(-) 0.37$ & 0.1 \\
\hline $\mathrm{CF}_{100 \mu \mathrm{l}} / \mathrm{CD}^{+} \mathrm{T}$ cells & $(-) 0.44$ & 0.05 \\
\hline $\mathrm{CD}^{+} \mathrm{T}$ cells $/ \mathrm{IL}-6$ & 0.57 & 0.01 \\
\hline $\mathrm{CD}^{+} \mathrm{T}$ cells/neopterin & $(-) 0.39$ & 0.1 \\
\hline TNF- $\alpha / C R P$ & 0.5 & 0.02 \\
\hline TNF- $\alpha /$ elastase & 0.47 & 0.05 \\
\hline TNF- $\alpha /$ neopterin & 0.44 & 0.05 \\
\hline CRP/elastase & 0.92 & 0.002 \\
\hline CRP/neopterin & 0.79 & 0.002 \\
\hline Elastase/neopterin & 0.72 & 0.002 \\
\hline
\end{tabular}

opterin $(r=-0.37, p<0.1)$ (Table 2). TNF- $\alpha$ correlated positively with CRP $(r=0.5$, $p<0.02)$, elastase $(r=0.47, p<0.05)$ and neopterin $(r=0.44, p<0.05)$ (Table 2). CRP correlated positively with elastase $(r=0.92$, $p<0.002)$ and neopterin $(r=0.79, p<0.002)$. Elastase correlated positively with neopterin $(r=0.72, p<0.002)$ (Table 2$)$.

\section{Discussion}

Clastogenic Factors

CFs are frequently but not exclusively found in several clinical conditions associated with a high incidence of malignancies. CF-induced clastogenesis is comparable to chemical clastogenesis, the only difference being that these clastogens are of endogenous origin. The endogenous clastogens induce chromosome damage not only in the cells of the patient (donor) but also in test cultures set up with blood of healthy persons. The latter is used as an assay for the detection of these clastogens. CFs are not single factors but mixtures of chromosome-damaging pro-oxidant substances. Biochemical analysis of the clastogenic plasma identified various chromosomedamaging agents, e.g., lipid peroxidation products such as 4-hydroxynonenal (34) and inosine triphosphate (35) and a monocyte-derived component (36), which was later identified as TNF- $\alpha$ (6).
The presence of CF in the plasma of HIV-1positive patients very early in the course of the disease (HIV patients with asymptomatic disease; Table 1) contributes to a shift in the pro-antioxidant balance toward the pro-oxidant side and may be of pathophysiological significance. Patients will be exposed to the clastogenic effects as long as the vicious cycle of CF and superoxide anion radical production is not interrupted (37). Pro-oxidant states can modulate the expression of genes related to cell growth and differentiation (38), and extracellular superoxide anion generation has been shown to activate proto-oncogenes and induce mutations at tumor suppressor loci via strand breakage and DNA sequence changes $(39,40)$. Whether the clastogenic effects continuously produced by circulating CF in HIV1-positive patients represents a risk factor for malignancies frequently observed in these patients deserves further study and follow-up. Recently, oxidative stress was suggested to be a viable clinical factor in AIDS Kaposi's sarcoma development (41). The finding that HIV-1-positive patients with Kaposi's sarcoma showed the highest CF values of all HIV patients (although statistically not significant, $p<0.08$ ) warrants further investigation. The presence of CF in the plasma of HIV-1-positive patients is not a general response to a viral infection because CFs were not increased in HIV-1-negative patients with zoster virus infection (Table 1). CF formation is not specific for HIV-1 infection because CF levels were also significantly elevated in HIV-1-negative patients with malignancies (Table 1). The negative correlation of $\mathrm{CF}$ with $\mathrm{CD} 4^{+} \mathrm{T}$ cells numbers $(r=-0.37, p<0.1)$, which reached statistical significance $(r=-0.44, p<0.05)$ when $0.1 \mathrm{ml}$ plasma ultrafiltrate was used for the cytogentic assay (see Materials and Methods), suggests that CF may have an indicator function for HIV disease activity. Decreasing $\mathrm{CD}^{+}{ }^{+} \mathrm{T}$ cell numbers predict progression of HIV-1 infection and the $\mathrm{CD} 4^{+} \mathrm{T}$ cell count is clinically very important for monitoring the disease (42).

\section{Cytokines}

A variety of injuries, such as infections, induce a systemic acute-phase reaction. This response is triggered by activation of several stress-sensitive protein kinases, involving reactive oxidants as mediators and leading to synthesis of acute phase cytokines such as TNF- $\alpha$, IL- 1 , and IL-2 (43). These cytokines are known to induce cellular 
production of reactive oxygen species, thereby perpetuating their own formation and action.

A complex network of immunoregulatory cytokines plays an important role in the pathophysiology of HIV-1 infection (44-48). Particularly TNF- $\alpha$ influences the progression of HIV-1 infection by stimulating viral transcription and replication processes, an action synergized by IL- 1 and IL-6 (12,49-52). Blood monocytes and macrophages from HIV-infected patients produce high levels of TNF- $\alpha$ (53-55) and IL-6 (55). Gene expression of human immunodeficiency virus depends on host cellular transcription factors, including nuclear transcription factor kappa

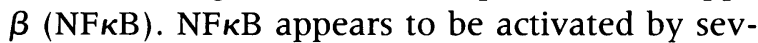
eral different signal transduction pathways (56). Reactive oxygen species have been implicated in $\mathrm{NF} \kappa \mathrm{B}$ activation, including possibly those generated by TNF- $\alpha$ and IL-1 (57). But recently, a reactive oxidant-independent pathway of $\mathrm{NF} \kappa \mathrm{B}$ activation has been discovered after stimulation with TNF- $\alpha$ and IL-1 $(58,59)$, and it is believed that activation of NF $\kappa \mathrm{B}$ can occur through redox-sensitive as well as redox-insensitive pathways $(60)$.

TNF- $\alpha$ is produced predominantely in response to host injury and infection and has cytotoxic activity against tumor cells. The cellular effects of TNF- $\alpha$ involve generation of oxygen radicals $(9,10,61)$. The net biological effects of TNF- $\alpha$ may often be beneficial to the host because of induction of tolerance to oxidative stress (62). However, overproduction of TNF- $\alpha$ is associated with serious pathological manifestations, including the wasting syndrome associated with neoplastic and infectious diseases, especially that associated with AIDS (63). In our study, TNF- $\alpha$ values were generally within the normal range, but there was a tendency towards elevated TNF- $\alpha$ concentration in HIV-1-negative patients with malignancies $(p<0.1)$ and in HIV-1-positive patients with malignancies $(p<0.09)$ in comparison with HIV-1-negative healthy controls.

IL-2 is produced by $\mathrm{T}$ and B lymphocytes, promotes proliferation of $\mathrm{T}$ cells after antigen stimulation, induces its own synthesis and stimulates growth of natural killer (NK) cells and lymphokine-activated killer (LAK) cells. At high concentrations it can trigger HIV production (64) and induce oxidative stress via stimulated production of reactive oxygen and nitrogen intermediates $(11,65)$. In HIV- 1 infection, IL-2 plasma concentration was reported to be decreased $(66,67)$, which is partially a result of $\mathrm{CD} 4^{+} \mathrm{T}$ cell depletion. Furthermore, the HIV glycoprotein gp1 20 suppresses secretion of IL-2 from CD $4^{+} \mathrm{T}$ cells (66). The decrease in IL-2 concentration causes a decline in NK and LAK cell activity, which contributes to the progression of immunosuppression (67). In addition, IL-2 possesses antiviral activity by inducing $\mathrm{CD} 8^{+} \mathrm{T}$ cells which inhibit HIV-1 production in infected $\mathrm{CD}^{+}{ }^{+} \mathrm{T}$ cells (68). These immunostimulatory and anti-HIV activities have led to therapeutical applications of IL-2 in HIV infection (69). Inhibition of HIV reproduction in HIV-infected patients by antiretroviral therapy is associated with a stimulation of IL-2 synthesis and a decreased incidence of opportunistic infections $(70,71)$. In contrast to the reports mentioned above $(66,67)$, in our HIV-1 positive patients, IL- 2 plasma levels were in the normal range (Table 1).

IL-6 physiologically promotes B cell growth and differentiation, $\mathrm{T}$ cell activation, and cytotoxic $\mathrm{T}$ cell differentiation, and it activates $\mathrm{NK}$ cells $(72,73)$. IL- 6 is synthesized by macrophages, $\mathrm{T}$ lymphocytes, fibroblasts, keratinocytes, and other cells. IL-6 concentration was reported to be increased in HIV-1-positive patients, particularly during the late course of the infection $(55,74)$. The HIV glycoproteins gp 120 and gp 160 induce synthesis of IL- 6 in mononuclear cells and CD4 ${ }^{+}$ T cells (75), and HIV-1 tat-protein stimulates IL-6 production in blood monocytes. This may explain increased IL-6 levels in HIV-1-positive patients with advanced disease and high viral replication rates (76). Increased levels of IL-6 during HIV-1 infection exert immunosuppressive effects, such as suppression of $\mathrm{T}$ lymphocyte response and inhibition of NK cells $(46,76)$, and it induces HIV-1 expression in infected $\mathrm{CD}^{+} \mathrm{T}$ cells and monocytes (74). High concentrations of IL-6 $(55,77)$ have been reported in HIV-1-positive patients and elevated levels of TNF- $\alpha$ and IL- 6 are associated with increased incidence of Kaposi's sarcoma in HIV-1-infected patients (78). In our study, IL-6 levels were within the physiological range, but they were significantly increased in HIV-l-negative patients with malignancies and in HIV-1-positive patients with asymptomatic disease and zoster, and significantly decreased in HIV patients with malignancies (Kaposi's sarcoma, lymphomas) in comparison with HIV-1-negative controls (Table 1). The decreased level of IL-6 in our HIV-1-positive patients with malignancies and the normal concentration of IL-2 in our HIV-1-positive patients could be explained by the effects of antiretroviral therapy. The statistically significant negative cor- 
relation of IL-6 with CF $(r=-0.43, p<0.05$; Table 2) indicates that IL- 6 is not a component of CF in HIV-1-infected patients.

Cytokines such as TNF- $\alpha$ and several interleukins exhibit genotoxic properties in human peripheral blood cell cultures (79). The mechanism of these genotoxic effects remains largely unknown. TNF- $\alpha$, IL-1, and IL-2 are glycopeptides with a molecular weight (m.w.) of $17 \mathrm{kD}$; the size of IL-6 is $26-32 \mathrm{kD}$. Thus these molecules pass through the filter YM30, which is used for the ultrafiltration of patients' plasma. TNF- $\alpha$ is among the identified components of clastogenic factors in vitro. In our study, there was only a tendency towards a positive correlation of CF with TNF- $\alpha(r=0.31, p<0.14)$. We have recently shown that 4-hydroxynonenal, which is significantly increased in HIV-1-infected patients (20) and possesses clastogenic activity in vitro (34), tends to correlate $(r=0.39, p<0.1)$ with $\mathrm{CF}$ of HIV-1-positive patients in vivo (8). The lack of a statistically significant correlation of $\mathrm{CF}$ values with TNF- $\alpha$ and 4-hydroxynonenal plasma concentrations in HIV-1-positive patients may be due to the small numbers of patients studied. However, it may also indicate that the composition of CF may vary from patient to patient, or that other unidentified components contribute to the clastogenic activity of the plasma. Further clinical studies with larger sample populations are necessary to analyze the composition of CF in HIV-1-positive patients.

\section{Acute Phase Proteins}

CRP (m.w. $105 \mathrm{kD}$ ) is a reliable indicator of acute inflammatory reactions, although it is frequently not elevated in chronic inflammatory conditions. It is synthesized by hepatocytes upon stimulation by IL-6 (80) and IL-1 (81) derived from monocytes/macrophages following tissue disruption and bacterial infection. The physiological function of CRP includes binding of a large variety of glycoproteins and phospholipids present in microorganisms, resulting in inactivation of these organisms. CRP stimulates macrophage functions, such as chemotaxis, phagocytosis, and oxidative burst, and inhibits neutrophil function. Besides its role as an indicator of inflammatory activity, CRP has cytotropic effects (82) and its anti-tumor effect in animals is possibly mediated via macrophages (83) and involves oxidative pathways. Our finding that CRP is not increased in patients with HIV-1 agrees with those of other reports $(13,84-86)$.

The acute-phase protein neopterin (a pyrazino-pyrimidine derivative) is induced by interferon-gamma (IF- $\gamma$ )-produced from $\mathrm{T}$ lymphocytes. Neopterin is released from monocytes/ macrophages and its concentration inversely correlates with absolute $\mathrm{CD} 4^{+} \mathrm{T}$ cell numbers in HIV-1-positive patients, thus it strongly predicts progression of disease from latency to AIDS $(14,87)$. In addition to its role as a sensitive indicator of disease activity in HIV-1 infection, neopterin has been suggested to be associated with the events regulating HIV-1 production and participates in destruction of the cellular immune system (14,87-89). In our study, neopterin levels were significantly increased in HIV-1-negative patients with zoster $(p<0.02)$ or malignancies $(p<0.03)$ and in HIV-1-positive patients with zoster $(p<0.05)$ or malignancies $(p<0.03)$ (Table 1). Neopterin was not elevated in HIV-1positive patients with asymptomatic disease. Neopterin (m.w. $253 \mathrm{kD}$ ) does not pass through the filter used for the ultrafiltration of patients' plasma, and there was no significant correlation of neopterin levels with CF activity in patients with HIV, indicating that the two parameters are not related. However, there was a tendency towards a negative correlation of $\mathrm{CD} 4^{+} \mathrm{T}$ cell numbers with neopterin concentration $(r=-0.37$, $p<0.1$; Table 2), implying an indicator function of neopterin levels in patients with HIV, which confirms the results of Baier-Bitterlich et al. (87).

Plasma levels of granulocyte elastase $(30 \mathrm{kD}$ glycoprotein) are increased during a variety of inflammatory reactions and increased release of elastase was found to be associated with HIV infection (90). This increase indicates stimulated neutrophil phagocytosis activity with release of activated oxygen species. TNF- $\alpha$ has been shown to prime neutrophils and macrophages to produce reactive oxidants (91). In our study, TNF- $\alpha$ levels correlated significantly positive with elastase $(r=0.47, p<0.05)$, CRP $(r=0.5, p<0.02)$, and neopterin $(r=0.44, p<0.05)$ (Table 2). Several studies have shown that increased elastase concentrations in patients' plasma indicate serious complications (92-94). In our study there was a tendency towards increased elastase levels only in HIV-positive patients with zoster $(p<$ $0.1)$, which indicates that most of our patients were vitally not endangered. There was no significant correlation of elastase concentration with CF activity in the patients with HIV (data 
not shown), indicating that the two parameters are not related.

Although CRP and elastase were not significantly increased in our patients, CRP correlated positively with elastase $(r=0.92, p<0.002)$ and neopterin $(r=0.79, p<0.002)$, and elastase correlated positively with neopterin $(r=0.72$, $p<0.002)$. This highly significant correlation indicates that the acute-phase proteins are useful as inflammatory markers, but their response differs in specificity and sensitivity.

\section{Conclusions}

CFs were significantly increased in all HIV-1positive patients. The highest $\mathrm{CF}$ values were observed in the HIV patients with Kaposi's sarcoma. CFs are not induced by viral infections in general, as they were not elevated in HIV-negative zoster patients. CFs are not specific for HIV infection, as they are significantly elevated in HIV-negative patients with malignancies. Although several cytokines have genotoxic properties in vitro, there was a tendency towards a positive correlation between TNF- $\alpha$ plasma concentration and CF values only in HIV patients. The lack of correlation of CF with IL- 6 and neopterin indicates that these factors do not contribute to the clastogenic activity of the HIV patient's plasma. The composition of CF may vary from patient to patient and/or other unidentified substances may contribute to the CF activity of HIV-1-infected patients. Since the formation and the action of clastogenic factors are modulated by superoxide anion radicals, we suggest that the superoxide-scavenging activity of the plasma is an important parameter that determines the expression of clastogenic activity. CFs are sensitive and long-lived markers of disturbed pro-oxidant/ antioxidant balance. They can be determined readily by cytogenetic analysis and may be useful for evaluation of drugs and other intervention strategies in HIV infection.

\section{Acknowledgments}

The assistance of Dr. Ackermann, Institute of Biomathematics, J. W. Goethe University Medical School, Frankfurt, in calculating the statistical analysis is highly appreciated.

\section{References}

1. Goh KO, Sumner H. (1968) Breaks in normal human chromosomes: Are they induced by a transferable substance in the plasma of irradiated persons exposed to total body irradiation? Radiation Res. 6: 51-60.

2. Hollowell JG, Littlefield LG. (1968) Chromosome damage induced by plasma from irradiated patients. An indirect effect of X-rays. Proc. Soc. Exp. Biol. Med. 129: 240-244.

3. Pant GS, Kamada N. (1977) Chromosome aberrations in normal leukocytes induced by the plasma of exposed individuals Hiroshima J. Med. Sci. 26: 240-244.

4. Faguet GB, Reichard SM, Welter DA. (1984) Radiation induced clastogenic plasma factors. Cancer Genet. Cytogenet. 12: 73-83.

5. Emerit I. (1994) Reactive oxygen species, chromosome mutation, and cancer: Possible role of clastogenic factors in carcinogenesis. Free Radic. Biol. Med. 16: 99-109.

6. Emerit I, Garban F, Vassy J, Levy A, Filipe P, Freitas J. (1996) Superoxide mediated clastogenesis and anticlastogenic effects of exogenous superoxide dismutase. Proc. Natl. Acad. Sci. U.S.A. 93: 12799-12804.

7. Edeas MA, Emerit I, Khalfoun Y, Laizizi Y, Cernjavski L, Levy A, Lindenbaum A. (1997) Clastogenic factors in HIV-1 infected patients activate HIV-1 replication in vitro: Inhibition by superoxide dismutase. Free Radic. Biol. Med. 23: 571-578.

8. Fuchs J, Emerit I, Levy A, Cernjavski I, Schöfer H, Milbradt R. (1995) Clastogenic factors in plasma of HIV-1 infected patients. Free Radic. Biol. Med. 19: 843-848.

9. Adamson GM, Billings RE. (1992) Tumor necrosis factor induced oxidative stress in isolated mouse hepatocytes. Arch. Biochem. Biophys. 294: 223-229.

10. Mihm S, Ennen J, Pessara U, Kurth R, Droege W. (1991) Inhibition of HIV-1 replication and NFkappaB activity by cysteine and cysteine derivatives. AIDS 5: 497-504.

11. Fauci AS, Schnittman SM, Poli G, Koening S, Pantaleo G. (1991) Immunopathogenic mechanisms in human immunodeficiency virus (HIV) infection. Ann. Int. Med. 114: 678-693.

12. Torresin A, Cassola G, Penco G, Giuliano C, Campanella A, Crisali MP, Persantelli N. (1997) C-reactive protein (CRP) and interleukin 6 (IL-6) in HIV related conditions. J. Acquir. Immune Defic. Syndr. Hum. Retrovirol. 14: A29.

13. Baier-Bitterlich G, Fuchs D, Wachter H. (1997) Chronic immune stimulation, oxidative stress, and apoptosis in HIV infection. Biochem. Pharmacol. 53: 755-776.

14. Yim CY, Hibbs JB Jr, McGregor JR, Galinsky RE, Samlowski WE. (1994) Use of $\mathrm{N}$-acetyl cysteine to increase intracellular glutathione during the in- 
duction of antitumor responses by IL-2. J. Immunol. 152: 5796-5805.

15. Sönnerborg A, Carlin G, Akerlund B, Jarstrand C. (1988) Increased production of malondialdehyde in patients with HIV infection. J. Infect. Dis. 20: 287-290.

16. Eck HP, Gmünder H, Hartmann M, Petzold D, Daniel V, Dröge W. (1989) Low concentration of acid soluble thiol (cystein) in the blood plasma of HIV-1 infected patients. Biol. Chem. Hoppe Seyler 370: $101-108$.

17. Buhl R, Holroyd KJ, Cantin AM, Jaffe HA, Wells FB, Saltini C, Crystal RG. (1989) Systemic glutathione-deficiency in symptom-free seropositive individuals. Lancet II: 1294-1298.

18. Folkers K, Langajoen P, Nara Y, Muratsu K, Komorowski J, Richardson PC, Smith TH. (1988) Biochemical deficiencies of coenzyme Q10 in HIV infection and exploratory treatment. Biochem. Biophys. Res. Commun. 153: 888-896.

19. Staal FJT, Roederer M, Israelski DM, Bubp J, Mole LA, McShane D, Deresinski SC, Ross W, Sussman H, Raju PA, Anderson MT, Moore W, Ela SW, Herzenberg LA, LA Herzenberg. (1992) Intracellular glutathione levels in $\mathrm{T}$ cell subsets decrease in HIV infected individuals. AIDS Res. Hum. Retroviruses 8: 305-311.

20. Fuchs J, Schöfer H, Ochsendorf F, Buhl R, Freisleben HJ, Unkelbach U, Janka S, Oster O, Siems W, Grune T, Esterbauer H, Milbradt R. (1994) Antioxidants and peroxidation products in the blood of HIV infected patients with HIV associated skin disease. Eur. J. Dermatol. 4: 148-153.

21. Favier A, Sappey C, Leclerc P, Faure P, Micoud M. (1994) Antioxidant status and lipid peroxidation in patients infected with HIV. Chem. Biol. Interact. 91: 165-180.

22. Halliwell B, Cross C. (1991) Reactive oxygen species, antioxidants, and acquired immunodeficiency syndrome. Arch. Intern. Med. 151: 29-31.

23. Fuchs J, Ochsendorf F, Schöfer H, Milbradt R, Rübsamen-Weigmann H. (1991) Oxidative imbalance in HIV infected patients. Med. Hypotheses 36: 60-64.

24. Baker DH, Wood RJ. (1994) Cellular antioxidant status and human immunodeficiency virus replication. Nutr. Rev. 50: 15-18.

25. Peterhans E. (1997) Oxidants and antioxidants in viral diseases: Disease mechanisms and metabolic regulation. J. Nutr. 127: 962S-965S.

26. Emerit I. (1990) Clastogenic factors: Detection and assay. Methods Enzymol. 555-564.

27. Emerit I, Filipe P, Meunier P, Auclair C, Freitas J, Deroussent A, Gouyette A, Fernandes A. (1997) Clastogenic activity in the plasma of scleroderma patients: A biomarker of oxidative stress. Dermatology 194: 140-146.

28. Kind CRH, Pepys MB. (1984) The role of serum $\mathrm{C}$-reactive protein (CRP) measurement in clinical practice. Int. Med. 5: 112-151.
29. Thomas L, Messinger M. (1993) Pathobiochemistry and laboratory diagnosis of inflammation. Lab. Med. 17: 179-194.

30. Barak M, Merzbach D, Gruener N. (1989) Neopterin measured in serum and tissue culture supernates by a competitive enzyme-linked immunosorbant assay. Clin. Chem. 35: 1467-1471.

31. Aoki C, Nishimoto N, Deguchi M, Yoshizaki K. (1955) Enzyme immunoassay for cytokines. Nippon Rinsho 53: 2290-2295.

32. Ferrua B, Aussel C, Fehlmann M. (1987) Human interleukin 2. Detection at the picomolar level by sandwich enzyme immunoassay. J. Immunol. Methods 97: 215-220.

33. De Groote D, Gevaert Y, Lopez M, Gathy R, Faucher F, Dehart I, Jadoul M, Radoux D, Franchimont P. (1993) Novel method for the measurement of cytokine production by a one-stage procedure. J. Immunol. Methods 163: 259-267.

34. Emerit I, Khan SH, Esterbauer H. (1991) Hydroxynonenal. A component of clastogenic factors. Free Radic. Biol. Med. 10: 371-377.

35. Auclair C, Gouyette A, Levy A, Emerit I. (1990) Clastogenic inosine nucleotide as components of the chromosome breakage factor in scleroderma patients. Arch. Biochem. Biophys. 278: 238-244.

36. Emerit I, Levy A, Camus JP. (1989) Monocyte derived clastogenic factor in rheumatoid arthritis. Free Radic. Biol. Med. 6: 245-250.

37. Emerit I. (1997) Clastogenic factors as biomarkers of oxidative stress. Their usefulness for evaluation of the efficiency of antioxidant treatments. Presented at Advanced Study Institute (supported by FEBS and NATO). Free Radicals, Oxidative Stress and Antioxidants. Pathological and Physiological Significance. Antalya, Turkey, May 24-June 4, 1997.

38. Cerutti P. (1985) Prooxidant states and tumor promotion. Science 227: 375-381.

39. Crawford D, Zbinden I, Amstad P, Cerutti P. (1988) Oxidant stress induces the proto-oncogenes c-fos and c-myc in mouse epidermal cells. Oncogene 3: 27-32.

40. Shibanuma MT, Kuroki T, Nose K. (1988) Induction of DNA replication and expression of protooncogene c-myc and c-fos in quiescent Balb/3T3 cells by xanthine oxidase. Oncogene 3: 17-21.

41. Mallery SR, Bailer RT, Hohl CM, Ng-Bautista CL, Ness GM, Livingston BE, Hout BL, Stephens RE, Brierley GP. (1995) Cultured AIDS-related Kaposi's sarcoma (AIDS-KS) cells demonstrate impaired bioenergetic adaptation to oxidant challenge: Implication for oxidant stress in AIDS-KS pathogenesis. J. Cell. Biochem. 59: 317-328.

42. Stein DS, Korvick JA, Vermund SH. (1992) $\mathrm{CD}^{+}$ lymphocyte cell enumeration for prediction of clinical course of human immunodeficiency virus disease: A review. J. Infect. Dis. 165: 352-363.

43. Koy A. (1996) Initiation of acute phase response 
and synthesis of cytokines. Biochim. Biophys. Acta 1317: 84-94.

44. Matasuyama T, Kobayashi N, Yamamoto N. (1991) Cytokines and HIV infection: is AIDS a tumor necrosis factor disease? AIDS 5: 1405-1417.

45. Poli G, Fauci AS. (1992) The effect of cytokines and pharmacologic agents on chronic HIV infection. AIDS Res. Hum. Retroviruses 8: 191-197.

46. Sinicco A, Biglino A, Sciandra M, Forno B, Pollono AM, Raiteri R, Gioannini, P. (1993) Cytokine network and acute primary HIV-1 infection. AIDS 7: 1167-1172.

47. Kundu SK, Merigan TC. (1997) Heterogeneity of cytokine functions in HIV infection. Immunology 91: 234-238.

48. Alonso $\mathrm{K}$, Pontiggia $\mathrm{P}$, Medenica R, Rizzo S. (1997) Cytokine patterns in adults with AIDS. Immunol. Invest. 26: 341-350.

49. Fauci AS. (1988) The human immunodeficiency virus: Infectivity and mechanism of pathogenesis. Science 239: 617-622.

50. Kruppa G, Thoma B, Machleidt T, Wiegmann K, Krönke K. (1992) Inhibition of tumor necrosis factor (TNF)-mediated NF- $\kappa$ B activation by selective blockage of the human $55 \mathrm{kDa}$ TNF receptor. J. Immunol. 148: 3152-3157.

51. Peterson PK, Gekker GM, Chao CC, Hu S, Edelman C, Balfour HH Jr. (1992) Human cytomegalovirus-stimulated peripheral blood mononuclear cells induce HIV-1 replication via a tumor necrosis factor-a mediated mechanism. J. Clin. Invest. 89: 574-580.

52. Emilie D, Fior R, Jarrousse B, Marfaing-Koka A, Merrien D, Devergne O, Crevon MC, Maillot MC, Galanaud P. (1994) Cytokines in HIV Infection. Int. J. Immunopharmacol. 16: 391-396.

53. Roux-Lombard P, Modoux C, Cruchaud A, Dayer JM. (1989) Purified blood monocytes from HIV I infected patients produce high levels of TNF alpha and IL-1. Clin. Immunol. Immunopathol. 50: 374384.

54. Lähdevirta J, Maury CPJ, Teppo AM, Repo H. (1988) Elevated levels of circulating cachectin/ tumor necrosis factor in patients with acquired immunodeficiency syndrome. Am. J. Med. 85: 289-291.

55. Foli A, Saville MW, May LT, Webb DSA, Yarchoan R. (1997) Effects of human immunodeficiency virus and colony-stimulating factors on the production of interleukin 6 and tumor necrosis factor alpha by monocyte-macrophages. AIDS Res. Hum. Retroviruses 13: 829-839.

56. Baldwin AS. (1996) The NF- $\kappa \mathrm{B}$ and $\mathrm{I} \kappa \mathrm{B}$ proteins: New discoveries and insights. Annu. Rev. Immunol. 14: 649-681.

57. Schreck R, Rieber P, Baeuerle PA. (1991) Reactive oxygen intermediates as apparently widely used second messengers in the activation of the NF $\kappa \mathrm{B}$ transcription factor and HIV-1. Eur. Mol. Biol. Org. J. 10: 2247-2258.
58. Bonizzi G, Dejardin E, Piret B, Piette J, Merville MP, Bours V. (1996) Interleukin- $1 \beta$ induces nuclear factor $\kappa \mathrm{B}$ in epithelial cells independently of the production of reactive oxygen intermediates. Eur. J. Biochem. 242: 544-549.

59. Brennan P, O'Neill LAJ. (1995) Effects of oxidants and antioxidants on nuclear factor $\kappa \mathrm{B}$ activation in three different cell lines: Evidence against an universal hypothesis involving oxygen radicals. Biochim. Biophys. Acta 1260: 167-175.

60. Legrand-Poels S, Zecchinon L, Piret B, Schoonbroodt S, Piette J. (1997) Involvement of different transduction pathways in NF- $\kappa \mathrm{B}$ activation by several inducers. Free Radic. Res. 27: 301-309.

61. Wong GHW. (1992) MnSOD Induction by TNF- $\alpha$ and its protective role. In: Beutler B (ed). Tumor Necrosis Factors: The Molecules and Their Emerging Role in Medicine. Raven Press, New York, pp. 473448.

62. Sato M, Sasaki M, Hojo H. (1995) Antioxidative roles of metallothionein and manganese superoxide dismutase induced by tumor necrosis factoralpha and interleukin-6. Arch. Biochem. Biophys. 316: $738-774$.

63. Beutler B, Cerami A. (1988) The history properties and biological effects of cachectin. Biochemistry 27: 7575-7578.

64. Weissman D, Daucher J, Barker T, Adelsberger J, Baseler M, Fauci AS. (1996) Cytokine regulation of HIV replication induced by dendritic cell-CD4positive T cell interactions. AIDS Res Hum. Retroviruses 12: 759-767.

65. Mikhalchik EV, Kharaeva ZF, Kovachuk IV, Shiyan SD, Korkina LG. (1996) Effect of interleukin-2 and gamma-interferon on "respiratory burst" in macrophages: Changes in the intracellular radical production and carbohydrate-specific interactions. Biologicheskie Membrany (Moscow) 13: 361-369.

66. Chirmule N, Kalyanaraman VS, Oyaizu N, Slade HB, Pahwa S. (1990) Inhibition of functional properties of tetanus antigen-specific T-cell clones by envelope glycoprotein GP120 of human immunodeficiency virus. Blood 75: 152-159.

67. Cauda R, Tumbarello M, Ortona L, Kennedy RC, Shuler KR, Chanh TC, Kanda P. (1990) Inhibition of lymphokine-activated killer activity during HIV infection: role of HIV-l gp4l synthetic peptides. Nat. Immun. Cell Growth Regul. 9: 366-375.

68. Kinter AL, Bende SM, Hardy EC, Jackson R, Fauci AS. (1995) Interleukin 2 induces $\mathrm{CD}^{+} \mathrm{T}$ cell mediated suppression of human immunodeficiency virus replication in $\mathrm{CD}^{+} \mathrm{T}$-cells and this effect overrides its ability to stimulates virus expression. Proc. Natl. Acad. Sci. U.S.A. 92: 10985-10989.

69. Garbe C. (1995) Perspectives of cytokine treatment in malignant skin tumors. Recent Results Cancer Res. 139: 349-369.

70. Clerici M, Roilides E, Butler KM, DePalma L, Venzon D, Shearer GM, Pizzo PA. (1992) Changes in 
T-helper cell function in human immunodeficiency virus infected children during didanosine therapy as a measure of antiretroviral activity. Blood 80: 2196-2202.

71. Zollner B, Feucht HH, Hamann A, Laufs R. (1995) Influence of exogenous interleukin-2 concentration on the isolation of human immunodeficiency virus. Microbiol. Immunol. 39: 117-121.

72. Kishimoto T. (1989) The biology of interleukin-6. Blood 74: 1-10.

73. Van Snick J. (1990) Interleukin-6: An overview. Annu. Rev. Immunol. 8: 253-278.

74. Zhou D, Munster A, Windurch RA. (1993) Pathologic concentrations of interleukin 6 inhibit $\mathrm{T}$ cell responses via induction of activation of TGF-beta. Microbiologia 16: 115-120.

75. Oyaizu N, Chirmule N, Ohnishi Y, Kalyanaraman VS, Pahwa S. (1991) Human immunodeficiency virus type 1 envelope glycoproteins gp120 and gp 160 induce interleukin-6 production in $\mathrm{CD}^{+}{ }^{+} \mathrm{T}$ cell clones. J. Virol. 65: 6277-6282.

76. Zauli G, Furlini G, Re MC, Milani D, Capitani S, La-Placa M. (1993) Human immunodeficiency virus type 1 (HIV-1) tat-protein stimulates the production of interleukin-6 (IL-6) by peripheral blood monocytes. Microbiologica 16: 115-1 20.

77. Marfaing-Koka A, Aubin JT, Grangeot-Keros L, Portier A, Benattar C, Merrien D, Agut H, Aucouturier P, Autran B, Wijdenes J. (1996) In vivo role of IL- 6 on the viral load and on immunological abnormalities of HIV-infected patients. J. Acquir. Immune Defic. Syndr. Hum. Retrovirol. 11: 59-66.

78. Samaniego F, Markham PD, Gallo RC, Ensoli B. (1995) Inflammatory cytokines induce AIDS-Kaposi's sarcoma derived spindle cells to produce and release basic fibroblast growth factor and enhance Kaposi's sarcoma like lesion formation in nude mice. J. Immunol. 154: 3582-3592.

79. Lazutka JR. (1996) Genetic toxicity of cytokines. Mutat. Res. 361: 95-105.

80. Duff GW. (1994) Cytokines and acute phase proteins in rheumatoid arthritis. Scand. J. Rheumatol. 100 (Suppl): 9-19.

81. Dinarello CA. (1984) Interleukin-1 and the pathogenesis of the acute-phase response. N. Engl. J. Med. 311: 1413-1416.

82. Polevishchikov AB, Nazarov PG. (1993) Immunocytotropic effects of $\mathrm{C}$-reactive protein. Immunologiya 4: 6-10.

83. Hennig, EM. (1995) C-reactive protein (CRP) and biological defence. Tidsskr. Nor. Laegeforen. 115: 1632-1635.

84. Syrjala H, Lahdevirta J, Ruutu P, Jokipii AMM, Ruutu T. (1990) Acute phase response in Pneumocystis carinii pneumonia. Scand. J. Infect. Dis. 22: 713-716.

85. Schmidt-Mathiesen A, Oreme G. (1990) C-reaktives Protein zur Erkennung postoperativer infektiöser Komplikationen. Chirurg 61: 895-899.

86. Vaishnavi C. (1996) C-reactive protein in bacterial infections. Immunol. Infect. Dis. 6: 139-144.

87. Baier-Bitterlich G, Wachter H, Fuchs D. (1996) Role of neopterin and 7,8-dihydroneopterin in human immunodeficiency virus infection: Marker for disease progression and pathogenic link. $J$. Acquir. Immune Defic. Syndr. Hum. Retrovirol. 13: 184-193.

88. Schobersberger W, Hoffmann G, Hobisch-Hagen P, Boeck G, Voelkl H, Baier-Bitterlich G, Wirleitner B, Wachter H, Fuchs D. (1996) Neopterin and 7,8-dihydroneopterin induce apoptosis in the rat alveolar epithelial cell line L2. FEBS Lett. 397: 263-268.

89. Baier-Bitterlich G, Fuchs D, Murr C, Reibenegger G, Werner-Felmayer G, Sgonc R, Boeck G, Dierich MP, Wachter H. (1995) Effect of neopterin and 7,8-dihydroneopterin on tumor necrosis factoralpha induced programmed cell death. FEBS Lett. 364: 234-239.

90. Jones DW, Winter $M$, Gallimore $M$, Mason C. (1994) Increased release of granulocyte elastase associated with HIV infection. Br. J. Haematol. 86 (Suppl 1): 91 .

91. Miesel R, Hartung R, Kroeger H. (1996) Priming of NADPH oxidase by tumor necrosis factor alpha in patients with inflammatory and autoimmune rheumatic disease. Inflammation 20: 427-438.

92. Dittmer H, Jochum M, Fritz H. (1986) Freisetzung von granulozytärer Elastase und Plasma-proteinveränderungen nach traumatisch-hämorrhagischem Schock. Unfallchirurg 89: 160-169.

93. Nast-Kolb D, Waydhas C, Jochum M. (1992) Biochemische Faktoren als objektive Parameter zur Prognoseabschätzung beim Polytrauma. Unfallchirurg 95: 59-66.

94. Windolf J, Oremek G, Inglis R, Zega A. (1994) Prospektive Validierung der PMN Elastase als Verlaufsparameter auf der unfallchirurgischen Intensivstation. Unfallchirurgie 20: 239-250. 